\title{
Utilization pattern and associated factors of maternal health care services in Haryana, India: a study based on district level household survey data
}

\author{
Shinjini Ray, Pravat Bhandari*, Jang Bahadur Prasad
}

Department of Population Studies, International Institute for Population Sciences, Mumbai, Maharashtra, India

Received: 25 December 2017

Revised: 17 January 2018

Accepted: 18 January 2018

\section{*Correspondence:}

Mr. Pravat Bhandari,

E-mail: pravat784@gmail.com

Copyright: () the author(s), publisher and licensee Medip Academy. This is an open-access article distributed under the terms of the Creative Commons Attribution Non-Commercial License, which permits unrestricted non-commercial use, distribution, and reproduction in any medium, provided the original work is properly cited.

\begin{abstract}
Background: Maternal health was one of the most important millennium development goals (MDGs), India didn't achieve by the year 2015. Since, India is a multicultural, social and multiregional country, where some of the regions have good social and demographic achievement while some are poor. Haryana is one of them, which has 146 maternal mortality ratio. The level of receiving antenatal care (ANC) in Haryana is quite low as compared to other states of India. Objective of present study was to Understand the extent of use of maternal health care services in Haryana as well as examining the role of antenatal care and other socio-economic factors on the utilization of maternal health services.

Methods: Bivariate analysis, chi-square test, and binary logistic regression have been used based on district level household and facility survey-4 data.

Results: The utilization of ANC (any and full), institutional delivery and post-delivery treatment seeking varies among women by literacy, age at first marriage, age at women and place of residence. Literate women are two times more likely to access ANC [odds ratio $(\mathrm{OR})=1.97$ (any $\mathrm{ANC}$ ), 1.95 (full $\mathrm{ANC}$ ), $\mathrm{p}<0.01$ ] and 1.52 times more likely to prefer institutional delivery [OR=1.52, $\mathrm{p}<0.01]$.

Conclusions: Empowering women through the encouragement of mother's education should be one of the most fundamental strategies to promote maternal health care services and reduce inequalities.
\end{abstract}

Keywords: Antenatal care, Institutional delivery, Haryana, DLHS, Post-delivery treatment, Women education

\section{INTRODUCTION}

Maternal health states the health condition of a woman at the time of pregnancy, delivery, and post-delivery (postpartum period). Maternal health care (MHC) services are the initiatives to ensure safe motherhood through promotive, preventive, curative and rehabilitative health care system. The topic maternal health-related issues become enlightened after International Conference on Population and Development (ICPD) in 1994, due to very high maternal mortality ratio in developing countries.
Maximum women in their reproductive age experienced serious health issues, more specifically death and disability due to pregnancy complication and childbirth from developing world. Although there is a variation in current estimates of maternal mortalities among the countries, still recent estimates show maternal mortality reached up to 230 in country like Nicaragua. ${ }^{1}$ About 800 women lose their life due to pregnancy or childbirthrelated complication around the globe every day, which accounts a number of 500,000 women death annually. ${ }^{2}$ India's maternal mortality ratio was estimated at 167 
maternal deaths per 100,000 live birthper 100,000 live birth in the year $2013 .^{3}$

Therefore, the way of reducing maternal death is possible through improving clinical interventions and by removing the barrier to access maternal health care services. ${ }^{4-7}$ The government of India launched many maternal health care programmes to reduce pregnancy and childbirth complication and maternal death. But unfortunately, the country is far away to reach the millennium development goal till the recent years. ${ }^{8}$ The study shows awareness and availability of modern maternal health care services are associated with utilization of services which has a significant impact on treatment seeking behavior and pregnancy outcome. ${ }^{9}$ Although there is a debate about the component of maternal health care services to be taken into consideration as a predictor of reproductive outcomes. Full antenatal care, safe delivery and postnatal care these three components have been allowed to measure the degree of utilization of maternity care services by Singh et al. ${ }^{9}$ A study by Panda et al. revealed that utilization of antenatal care (ANC) services and promotion of institutional deliveries play a critical role in safe motherhood. ${ }^{10}$

It has been evidenced by the studies that utilization of maternal health care services among women in their reproductive age, influenced by several demographic and socio-economic factors. Study based on the National Family Health Survey exemplified education of women scales up the women's attitudes towards utilization of maternal health care services. ${ }^{11-13}$ Factors like Socioeconomic status, religion, matriarchal system are a significant aspect of utilizing MHC services. ${ }^{14}$ Age, caste, type of residence, the standard of living of women also significantly associated with utilization of various maternal health care services in India. ${ }^{15}$ Study also reveals that accessibility of services depend upon the types of services available in various states. ${ }^{16}$

India is a multi socio-cultural and multiregional country, where some of the regions have good social and demographic achievement while some are poor. Haryana is one of them, which has 146 maternal mortality ratio. The level of receiving full antenatal care (ANC) in Haryana is quite low as compared to other states of India. In this context, it is attention-grabbing to know the utilization of maternal health care services and the associated factors.

Thus, the present study attempts to go over the extent of use of maternal health care services in Haryana and effort has also been made to examine the role of antenatal care and other socio-economic factors on the utilization of maternal health services.

\section{METHODS}

The study has been done using fourth round of district level household and facility survey (DLHS-4) dataset. ${ }^{17}$
This survey has been extended over 20 states and 6 union territories throughout the country. Here we have considered the data of Haryana state, the survey was conducted during the months of June to December of 2013, which covered 21 districts from all parts of the state. DLHS is conducted by the Ministry of Health and Family Welfare (MOHFW) and Government of India (GOI).

The Ministry of Health and Family Welfare, Government of India, introduced the process of conducting DLHS-4 and International Institute for Population Sciences (IIPS) contributed as the leading agency to design and carry out the survey. Here we have used DLHS-4 dataset because this survey focussed specifically to gather information about maternal and child health care services.

A number of 28,776 ever-married women (aged 15-49 years) in Haryana interviewed at the time of the survey conducted. Out of that 8458 women are included for present study on the basis of last five years birth (live and still) history. In this context, the study includes those 8458 women who had their last birth (live and still) since the time period of January 2008.

\section{Dependent variables}

In this study, we have considered three basic reproductive health services provided under various schemes by GOI namely antenatal care, institutional delivery, and postdelivery services as a measure of $\mathrm{MCH}$ utilization as well as dependent variables. In addition to this we have included another variable called post-delivery complication to make this study more effective one.

Antenatal care is a service-based initiative by National Rural Health Mission (NRHM) under MOHFW, GOI to make stronger reproductive and child health care, launched in India in April 2005. Auxiliary nurse midwife (ANM), doctor and other health professional are involved in providing ANC in various health sectors encompass several health check-ups. Minimum three ANC checkups during pregnancy, accepted as a preventive way of pregnancy and childbirth-related complication. This way ANC has been classified into two separate groups by the number of ANC visits and other criteria fulfillment.

\section{Any ANC}

Those women received any antenatal care like four and above antenatal visits or received two or more Tetanus Toxoid vaccine during pregnancy or took 90+ Iron Folic Acid (IFA) tablets or syrups have been considered as any ANC.

\section{Full ANC}

It has been defined as at least four ANC check-ups, consumed 90+ IFA tablets, two or more TT vaccine during pregnancy are grouped as full ANC. 


\section{Institutional delivery}

Institutional delivery is endorsed by NRHM through Janani Suraksha Yojana (JSY) to prevent maternal death. Those women delivered their baby in any health institute (Govt. or Private) considered as institutional delivery.

\section{Post-delivery complication}

Women who suffered from high fever, low abdominal pain, foul smelling, excessive bleeding, convulsion and severe headache after delivery considered as major postdelivery complication. After combining all these aspects a new variable post-delivery complication has been computed.

\section{Sought treatment for post delivery complication.}

Those women received treatment for post-delivery complication categorized in this group.

\section{Independent variables}

The independent variables used for the study are a range of socio-economic and demographic phenomenon such as age of women ( $<18$ and 18 and above); age at first marriage ( $<18$ and 18 and above); religion (Hindu, Muslim and other); caste (SC/ST, OBC and other); locality of the household (rural and urban); wealth index (poor, middle, rich); type of delivery (normal and other). The first category in each variable shows the reference category.

\section{Statistical analysis}

To fulfil all the objectives of this study a number of statistical analysis such as bivariate analysis, chi-square test, and binary logistic regression model have been carried out. Chi-square test helps to understand the association of any ANC, full ANC, institutional delivery and sought treatment for post delivery complication with different socio-economic and demographic variables of women and making the comparison among them.

Logistic regression has been used to predict the odds ratios and to identify the significance of maternal health care services with background characteristics of women. Confidence Intervals (CI) is also given to show the level of inequality in utilization of maternal health care among the social group by their wealth index. The Stata software package (StataCorp LP, v. MP 14.0) was used for all the statistical analysis.

\section{RESULTS}

\section{Utilization of antenatal care services among women}

Firstly, the study focuses on utilization of antenatal care according to selected background characteristics (Table 1 ). With regard to the highest proportion of women, who are in the age group 18 and above have received a maximum share of ANC services i.e. any ANC (70.7\%) and full ANC (16.2\%). Whereas less than 18 years old mothers are utilizing a less proportion of ANC services with significant differences of 18 and above mothers. Result shows, women age at first marriage made a partition in receiving antenatal care services. Women, marrying after age 18 and above receiving relatively higher antenatal care services (any $\mathrm{ANC}=69.9 \%$, full $\mathrm{ANC}=16.3 \%$ ) than those women are marrying before 18 years of age.

Table 1: Percent distribution of women received antenatal care (ANC) by selected background characteristics in Haryana, 2012-13.

\begin{tabular}{|c|c|c|c|}
\hline $\begin{array}{l}\text { Background } \\
\text { characteristics }\end{array}$ & $\begin{array}{l}\text { Any } \\
\text { ANC }\end{array}$ & $\begin{array}{l}\text { Full } \\
\text { ANC }\end{array}$ & $\mathbf{N}$ \\
\hline \multicolumn{4}{|l|}{ Women age } \\
\hline Less than 18 & 60.5 & 8.3 & 626 \\
\hline 18 and above & 70.7 & 16.2 & 7832 \\
\hline \multicolumn{4}{|c|}{ Age at first marriage ${ }^{a}$} \\
\hline Less than 18 & 62.5 & 10.8 & 2043 \\
\hline 18 and above & 69.9 & 16.3 & 6415 \\
\hline \multicolumn{4}{|l|}{ Religion $^{\text {a }}$} \\
\hline Hindu & 70 & 15.6 & 7611 \\
\hline Muslim & 39.9 & 5.4 & 561 \\
\hline Others & 74.3 & 16.9 & 286 \\
\hline \multicolumn{4}{|l|}{ Caste $^{a}$} \\
\hline $\mathrm{SC} / \mathrm{ST}$ & 62 & 11.8 & 3043 \\
\hline OBC & 67.8 & 15.5 & 2486 \\
\hline Others & 75 & 17.8 & 2929 \\
\hline \multicolumn{4}{|c|}{ Women education $^{a}$} \\
\hline Illiterate & 48.4 & 6.7 & 1804 \\
\hline Literate & 73.6 & 17.2 & 6654 \\
\hline \multicolumn{4}{|c|}{ Place of residence $^{a}$} \\
\hline Rural & 64.3 & 12.5 & 5139 \\
\hline Urban & 75.3 & 19.6 & 3319 \\
\hline \multicolumn{4}{|l|}{ Wealth index ${ }^{a}$} \\
\hline Poor & 57.9 & 9.7 & 3554 \\
\hline Middle & 70.3 & 16.3 & 1704 \\
\hline Rich & 78.8 & 20.3 & 3200 \\
\hline Haryana & 70.8 & 14.9 & 8458 \\
\hline
\end{tabular}

Note: Percentage are based on weighted analysis and sample size $(\mathrm{N})$ are un-weighted. ${ }^{\text {TThe }}$ Chi-Square statistic significant at 95\% CI; $\mathrm{ANC}=$ Antenatal Care, Poor=Poorest + Poorer, Rich=Richest + Richer, $\mathrm{SC}=$ Scheduled Caste, $\mathrm{ST}=$ Scheduled Tribe, $\mathrm{OBC}=$ Other Backward Classes.

Religion-wise Muslims (any $\mathrm{ANC}=39 \%$, full $\mathrm{ANC}=5.4 \%$ ) are backward compared to Hindu (any $\mathrm{ANC}=70 \%$, full $\mathrm{ANC}=15.6 \%$ ) and others (any $\mathrm{ANC}=74.3 \%$, full $\mathrm{ANC}=6.9 \%$ ) in terms of attaining antenatal care services. Result also suggests that SC and ST category women are less involved with any type of antenatal care services while other categories are significantly higher share in receiving antenatal care services. 
Education of women also playing a crucial role in getting antenatal care services. Literate women are receiving almost two times more full ANC (17.2\%) services. Urban women have more access to antenatal care services than rural women.

Wealth wise rich people are close to antenatal care services than poor and middle economic group of people. In Haryana, almost 71 percent women receive any ANC, 15 percent full ANC. As per result, there is a huge gap between any ANC (70.8\%) and full ANC (14.9\%) services utilization within the state.

Variation in receiving any $A N C$ and full $A N C$ : results from logistic regression analysis

It is evident from the output of bivariate logistic regression (Table 2) that religion, caste, education, wealth index, and place of residence of women is significantly associated with utilization of any ANC and full ANC services. But women age at first marriage is only associated with utilization of full ANC.

Muslim women are utilizing almost 56 percent less any ANC (Odds Ratio, OR=0.441, $\mathrm{p} \leq 0.01$ ) and 48 percent less full ANC $(\mathrm{OR}=0.523, \mathrm{p} \leq 0.01)$ as compared to Hindu women. Social group wise, $\mathrm{OBC}$ and other category women are significantly more utilizing any ANC and full ANC services than SC/ST groups.

There is a positive relationship between education of women and any ANC and full ANC. The literate women receive nearly two times more any ANC (OR=1.969, $\mathrm{p} \leq 0.01)$ and full $\mathrm{ANC}(\mathrm{OR}=1.955, \mathrm{p} \leq 0.01)$ services than illiterate women.

Table 2: Variation in any ANC and full ANC: output from logistic regression analysis.

\begin{tabular}{|c|c|c|c|c|c|c|}
\hline \multirow{2}{*}{$\begin{array}{l}\text { Background } \\
\text { characteristics }\end{array}$} & \multicolumn{3}{|l|}{ Any ANC } & \multicolumn{3}{|l|}{ Full ANC } \\
\hline & Odds Ratio & $95 \% \mathrm{CI}$ & $P$ value & Odds Ratio & $95 \% \mathrm{CI}$ & $P$ value \\
\hline \multicolumn{7}{|l|}{ Women age } \\
\hline \multicolumn{7}{|l|}{ Less than $18 \AA$} \\
\hline 18 and above & 1.009 & $0.239-4.248$ & 0.990 & 1.016 & $0.124-8.324$ & 0.988 \\
\hline \multicolumn{7}{|c|}{ Age at first marriage } \\
\hline \multicolumn{7}{|c|}{ Less than $18 \AA$} \\
\hline 18 and above & 1.078 & $0.963-1.206$ & 0.187 & $1.279 * * *$ & $1.090-1.501$ & 0.002 \\
\hline \multicolumn{7}{|l|}{ Religion } \\
\hline \multicolumn{7}{|l|}{ Hindu® } \\
\hline Muslim & $0.441 * * *$ & $0.364-0.533$ & 0.000 & $0.523 * * *$ & $0.359-0.752$ & 0.001 \\
\hline Others & 0.998 & $0.753-1.322$ & 0.989 & 0.864 & $0.621-1.202$ & 0.386 \\
\hline \multicolumn{7}{|l|}{ Caste } \\
\hline \multicolumn{7}{|l|}{$\mathrm{SC} / \mathrm{ST} \circledast$} \\
\hline OBC & $1.259 * * *$ & $1.117-1.430$ & 0.000 & $1.249 * * *$ & $1.065-1.464$ & 0.006 \\
\hline Others & $1.268 * * *$ & $1.119-1.437$ & 0.000 & 1.102 & $0.942-1.291$ & 0.223 \\
\hline \multicolumn{7}{|c|}{ Education of Women } \\
\hline \multicolumn{7}{|c|}{ Illiterate $®$} \\
\hline Literate & $1.969 * * *$ & $1.740-2.227$ & 0.000 & $1.955^{* * *}$ & $1.579-2.419$ & 0.000 \\
\hline \multicolumn{7}{|c|}{ Place of Residence } \\
\hline \multicolumn{7}{|c|}{ Rural® } \\
\hline Urban & $1.358 * * *$ & $1.222-1.509$ & 0.000 & $1.439 * * *$ & $1.268-1.633$ & 0.000 \\
\hline \multicolumn{7}{|l|}{ Wealth Index } \\
\hline \multicolumn{7}{|l|}{ Poor® } \\
\hline Middle & $1.252 * * *$ & $1.093-1.433$ & 0.001 & $1.394 * * *$ & $1.163-1.671$ & 0.000 \\
\hline Rich & $1.657 * * *$ & $1.453-1.890$ & 0.000 & $1.570 * * *$ & $1.331-1.853$ & 0.000 \\
\hline
\end{tabular}

Note: ${ }^{\circledR}$ denotes Reference Category; $* * * p \leq 0.01, * * p \leq 0.05, * p<=0.1$; Dependent variables: Any ANC (No=0, Yes $\left.=1\right)$, Full ANC $(\mathrm{No}=0$, Yes $=1) ;$ Poor $=$ Poorest + Poorer, Rich $=$ Richest + Richer, $\mathrm{SC}=$ Scheduled Caste, $\mathrm{ST}=$ Scheduled Tribe

The urban dwellers have significantly 36 percent higher chance in receiving any $\mathrm{ANC}$ and 44 percent in receiving full ANC. There is a positive association between wealth index and getting any ANC and full ANC.
Odds ratios from the table clearly depict that as the standard of living increases the utilization of any ANC and full ANC are also increased significantly. 


\section{Place of delivery preferred by women}

Table 3 displays the percentage distribution of women according to their place of delivery, by some selected background characteristics. About 45 percent of women aged below 18 years prefer government (Govt.) hospitals and 23 percent private hospitals. However, women who are below 18 years of age at first marriage are more likely to prefer home $(31.1 \%)$ than the other counterpart. Muslim women usually deliver their child in the home $(53.7 \%)$ than govt. (25.9\%) and private hospital (18.8\%). Caste wise other group of women less prefer home as a delivery place $(15.1 \%)$. However, interestingly, illiterate women are delivering their child in Govt. hospital $(43.3 \%)$ than private, but delivery at home $(40.3 \%)$ still high for illiterate women.

Table 3: Percent distribution of women according to place of delivery by selected background characteristics in Haryana, 2012-13.

\begin{tabular}{|c|c|c|c|c|}
\hline \multirow[t]{2}{*}{ Background characteristics } & \multicolumn{4}{|c|}{ Place of delivery } \\
\hline & Government & Private & Home & $\mathbf{N}$ \\
\hline \multicolumn{5}{|l|}{ Women age } \\
\hline Less than 18 & 44.9 & 22.7 & 32.4 & 626 \\
\hline 18 and above & 40.3 & 39.8 & 19.9 & 7832 \\
\hline \multicolumn{5}{|l|}{ Age at first marriage ${ }^{a}$} \\
\hline Less than 18 & 42.7 & 25.7 & 31.1 & 2043 \\
\hline 18 and above & 42.2 & 37.5 & 19.7 & 6415 \\
\hline \multicolumn{5}{|l|}{ Religion $^{\mathrm{a}}$} \\
\hline Hindu & 43.9 & 35.2 & 20.5 & 7611 \\
\hline Muslim & 25.9 & 18.8 & 53.7 & 561 \\
\hline Others & 33.9 & 51.3 & 13.7 & 286 \\
\hline \multicolumn{5}{|l|}{ Caste $^{\mathrm{a}}$} \\
\hline SC/ST & 47.6 & 24.2 & 27.5 & 3043 \\
\hline OBC & 41.6 & 33.1 & 24.8 & 2486 \\
\hline Others & 37.4 & 47.2 & 15.1 & 2929 \\
\hline \multicolumn{5}{|l|}{ Women education ${ }^{a}$} \\
\hline Illiterate & 43.3 & 15.4 & 40.3 & 1804 \\
\hline Literate & 42.1 & 39.9 & 17.6 & 6654 \\
\hline \multicolumn{5}{|l|}{ Place of residence ${ }^{a}$} \\
\hline Rural & 45.7 & 28.7 & 25 & 5139 \\
\hline Urban & 36.1 & 45.8 & 17.8 & 3319 \\
\hline \multicolumn{5}{|l|}{ Wealth Index ${ }^{a}$} \\
\hline Poor & 47.9 & 19 & 33.2 & 3554 \\
\hline Middle & 44.8 & 34 & 21.6 & 1704 \\
\hline Rich & 34.7 & 53.6 & 11.5 & 3200 \\
\hline \multicolumn{5}{|l|}{ Any ANCa } \\
\hline No & 37.3 & 18.5 & 43.1 & 2568 \\
\hline Yes & 44.6 & 41.8 & 13.3 & 5890 \\
\hline \multicolumn{5}{|l|}{ Full ANC ${ }^{a}$} \\
\hline No & 41.7 & 33 & 24.7 & 7166 \\
\hline Yes & 46.1 & 43.9 & 10.1 & 1292 \\
\hline Haryana & 42.4 & 34.6 & 23 & 8458 \\
\hline
\end{tabular}

Note: Percentage are based on weighted analysis and sample size $(\mathrm{N})$ are un-weighted; ${ }^{\text {TThe }}$ Chi-Square statistic significant at $99 \%$ CI; $\mathrm{ANC}=$ Antenatal Care, $\mathrm{SC}=$ Scheduled Caste, $\mathrm{ST}=$ Scheduled Tribe, OBC $=$ Other Backward Classes, Poor $=$ Poorest + Poorer, Rich=Richest + Richer.

Rural women $(45.7 \%)$ prefer to go Govt. hospital for delivery than urban women $(36.1 \%)$, while more rich women are admitted to private hospital for delivery. But poor and middle economic group women are admitted to Govt. hospital than a private hospital. Among women those who have received any ANC out of them almost 45 percent of them prefer their delivery in govt. hospital, around 42 percent in private and 13 percent at home. Those who have received full ANC among them only 10 percent women prefer to deliver at home while the majority of women received institutional delivery $(46.1 \%$ in Govt. hospital and $43.9 \%$ in private hospital). 
Variation in receiving institutional delivery: results from logistic regression analysis

It is depicted in Table 4 that the possibility of using institutional delivery reduces as the age of first marriage of women decreases. Women got married 18 years and above are $34.7(\mathrm{OR}=1.347, \mathrm{p} \leq 0.01)$ percent more likely to avail institutional delivery. Women from Muslim communities were having 57.6 percent $(\mathrm{OR}=0.424$, $\mathrm{p} \leq 0.01)$ less chance in receiving Institutional delivery in comparison with Hindu women. It is worth noting that literate mothers utilizing govt. or private services for institutional delivery 52 percent more than illiterate mothers. There is a positive association between wealth index and place of delivery, as wealth index increases the utilization of institutional delivery purpose also increases. The expected odds of utilizing institutional delivery among rich people were around 1.95. The key finding which has been emerged from this table, those who had received any type of ANC they are 3.61 (OR=3.612, $\mathrm{p} \leq 0.01$ ) times more likely to visit for institutional delivery and women who received full ANC the chance for availing institutional delivery is nearly 32 percent more than who had not received.

Table 4: Variation of women received institutional delivery: results from logistic regression analysis.

\begin{tabular}{|c|c|c|c|}
\hline Background characteristics & Odds Ratio & $95 \%$ Confidence Interval & P value \\
\hline \multicolumn{4}{|l|}{ Women Age } \\
\hline \multicolumn{4}{|l|}{ Less than $18 \AA$} \\
\hline 18 and above & 0.915 & $0.171-4.875$ & 0.918 \\
\hline \multicolumn{4}{|l|}{ Age at First Marriage } \\
\hline \multicolumn{4}{|l|}{ Less than $18 ®$} \\
\hline 18 and above & $1.347 * * *$ & $1.188-1.528$ & 0.000 \\
\hline \multicolumn{4}{|l|}{ Religion } \\
\hline \multicolumn{4}{|l|}{ Hindu ${ }^{\circledR}$} \\
\hline Muslim & $0.424 * * *$ & $0.346-0.519$ & 0.000 \\
\hline Others & 1.082 & $0.760-1.540$ & 0.660 \\
\hline \multicolumn{4}{|l|}{ Caste } \\
\hline \multicolumn{4}{|l|}{$\mathrm{SC} / \mathrm{ST} \circledast$} \\
\hline $\mathrm{OBC}$ & 1.092 & $0.952-1.251$ & 0.206 \\
\hline Others & $1.310 * * *$ & $1.130-1.519$ & 0.000 \\
\hline \multicolumn{4}{|l|}{ Education of Women } \\
\hline \multicolumn{4}{|l|}{ Illiterate $\AA$} \\
\hline Literate & $1.520 * * *$ & $1.325-1.743$ & 0.000 \\
\hline \multicolumn{4}{|l|}{ Place of Residence } \\
\hline \multicolumn{4}{|l|}{ Rural® } \\
\hline Urban & 1.037 & $0.917-1.172$ & 0.562 \\
\hline \multicolumn{4}{|l|}{ Wealth Index } \\
\hline \multicolumn{4}{|l|}{ Poor® } \\
\hline Middle & $1.215^{* *}$ & $1.041-1.418$ & 0.013 \\
\hline Rich & $1.946 * * *$ & $1.661-2.279$ & 0.000 \\
\hline \multicolumn{4}{|l|}{ Any ANC } \\
\hline \multicolumn{4}{|l|}{$\mathrm{No} \circledast$} \\
\hline Yes & $3.612 * * *$ & $3.206-4.068$ & 0.000 \\
\hline \multicolumn{4}{|l|}{ Full ANC } \\
\hline \multicolumn{4}{|l|}{$\mathrm{No} \circledR$} \\
\hline Yes & $1.316 * * *$ & $1.070-1.618$ & 0.009 \\
\hline
\end{tabular}

\section{Post-delivery complication and its treatment seeking}

Table 5 shows that nearly 15 percent of women face postdelivery complication and among them, 55.3 percent consult or seek treatment in Haryana. Almost 16 percent of Muslim women are suffering from post-delivery complication. The post-delivery complication is slightly higher among OBC (16.7\%) group women rather than SC/ST $(15.2 \%)$ and others $(13.8 \%)$. Only 48 percent illiterate women go for seeking treatment. Most of the women residing in rural $(14.7 \%)$ area face more postdelivery complication. Due to poverty, 52 percent women 
are able to seek treatment although the proportion of post-delivery problem is higher among them. Women who did not receive any ANC only 41 percent of them go to seek treatment for post-delivery complication. Only around 45 percent women who prefer a place of delivery at home, go for seeking treatment.

Table 5: Percent distribution of women suffered from post-delivery complication and sought treatment according to selected background characteristics in Haryana, 2012-13.

\begin{tabular}{|c|c|c|c|c|}
\hline Background characteristics & Post delivery complication & $\mathbf{N}$ & Sought treatment & $\mathbf{N}$ \\
\hline \multicolumn{5}{|l|}{ Women age } \\
\hline Less than 18 & 17.3 & 626 & 49.4 & 108 \\
\hline 18 and above & 14.9 & 7832 & 56.3 & 1176 \\
\hline \multicolumn{5}{|l|}{ Age at first marriage } \\
\hline Less than 18 & 15.0 & 2043 & 52.3 & 306 \\
\hline 18 and above & 15.3 & 6415 & 56.3 & 978 \\
\hline \multicolumn{5}{|l|}{ Religion* } \\
\hline Hindu & 15.0 & 7611 & 54.9 & 1137 \\
\hline Muslim & 15.5 & 561 & 54.0 & 91 \\
\hline Other & 20.1 & 286 & 65.9 & 56 \\
\hline \multicolumn{5}{|l|}{ Caste** } \\
\hline SC/ST & 15.2 & 3043 & 54.2 & 459 \\
\hline OBC & 16.7 & 2486 & 56.1 & 419 \\
\hline Other & 13.8 & 2929 & 55.9 & 406 \\
\hline \multicolumn{5}{|l|}{ Women education $* * *$} \\
\hline Illiterate & 15.7 & 1804 & 47.5 & 285 \\
\hline Literate & 15.1 & 6654 & 57.6 & 999 \\
\hline \multicolumn{5}{|l|}{ Place of residence* } \\
\hline Rural & 14.7 & 5139 & 56.9 & 749 \\
\hline Urban & 16.2 & 3319 & 52.6 & 535 \\
\hline \multicolumn{5}{|l|}{ Wealth index* } \\
\hline Poor & 15.8 & 3554 & 51.9 & 562 \\
\hline Middle & 15.6 & 1704 & 55.5 & 248 \\
\hline Rich & 14.3 & 3200 & 58.8 & 458 \\
\hline \multicolumn{5}{|l|}{ Any ANC $* * *$} \\
\hline No & 11.1 & 2650 & 41.0 & 299 \\
\hline Yes & 17.1 & 5808 & 59.7 & 985 \\
\hline \multicolumn{5}{|l|}{ Full ANC $* * *$} \\
\hline No & 14.8 & 7166 & 53.3 & 1058 \\
\hline Yes & 17.4 & 1292 & 65.3 & 226 \\
\hline \multicolumn{5}{|l|}{ TT**** } \\
\hline No & 11.7 & 2811 & 40.3 & 333 \\
\hline Yes & 17.0 & 5647 & 60.6 & 951 \\
\hline \multicolumn{5}{|l|}{ IFA*** $^{* * *}$} \\
\hline No & 14.1 & 6228 & 52.6 & 882 \\
\hline Yes & 18.2 & 2230 & 61.3 & 402 \\
\hline \multicolumn{5}{|l|}{ Place of delivery**** } \\
\hline Home & 12.6 & 1918 & 45.1 & 239 \\
\hline Government & 15.9 & 3545 & 53.5 & 566 \\
\hline Private & 16.0 & 2995 & 63.0 & 479 \\
\hline \multicolumn{5}{|l|}{ Type of delivery**** } \\
\hline Normal & 14.4 & 7506 & 52.2 & 239 \\
\hline other & 21.9 & 952 & 72.5 & 1045 \\
\hline Haryana & 15.2 & 8458 & 55.3 & 1284 \\
\hline
\end{tabular}

Note: The Chi-square statistic significant when $* * * \mathrm{p} \leq 0.01, * * \mathrm{p} \leq 0.05, * \mathrm{p} \leq 0.1 ; \mathrm{SC}=$ Scheduled Caste, $\mathrm{ST}=\mathrm{Scheduled}$ Tribe, OBC $=$ Other Backward Classes, Poor $=$ Poorest + Poorer, Rich $=$ Richest + Rich . 
Variation in treatment seeking for post-delivery complications: results from logistic regression analysis

From Table 6 it is evident that religion is significantly associated with treatment seeking for post-delivery complications. Women who have taken any ANC and full ANC during pregnancy have $1.98(\mathrm{OR}=1.980, \mathrm{p} \leq 0.01)$ times and $1.27(\mathrm{OR}=1.268, \mathrm{p} \leq 0.01)$ times respectively higher chance to consult doctor for treatment seeking for post-delivery complications. Type of delivery also has significant relation with seeking treatment. Women who gave their childbirth other than normal delivery had 2.37 $(\mathrm{OR}=2.367, \mathrm{p} \leq 0.01)$ times more chance of treatment seeking for post-delivery complications.

Table 6: Variation in treatment seeking for post-delivery complications: results from logistic regression analysis.

\begin{tabular}{|c|c|c|c|}
\hline Background characteristics & Odds ratio & 95\% Confidence interval & P value \\
\hline \multicolumn{4}{|l|}{ Women age } \\
\hline \multicolumn{4}{|l|}{ Less than $18^{\circledR}$} \\
\hline 18 and above & 1.106 & $0.691-1.770$ & 0.673 \\
\hline \multicolumn{4}{|l|}{ Age at First Marriage } \\
\hline \multicolumn{4}{|l|}{ Less than $18^{\circledR}$} \\
\hline 18 and above & 1.017 & $0.772-1.338$ & 0.904 \\
\hline \multicolumn{4}{|l|}{ Religion } \\
\hline \multicolumn{4}{|l|}{$\operatorname{Hindu}^{\circledR}$} \\
\hline Muslim & $1.194 * *$ & $0.746-1.912$ & 0.028 \\
\hline Other & 1.524 & $0.855-2.096$ & 0.153 \\
\hline \multicolumn{4}{|l|}{ Caste } \\
\hline \multicolumn{4}{|l|}{$\mathrm{SC} / \mathrm{ST}^{\circledR}$} \\
\hline $\mathrm{OBC}$ & 1.037 & $0.781-1.376$ & 0.799 \\
\hline Other & 0.853 & $0.629-1.155$ & 0.305 \\
\hline \multicolumn{4}{|l|}{ Education of women } \\
\hline \multicolumn{4}{|l|}{ Illiterate $^{\circledR}$} \\
\hline Literate & $1.031 * *$ & $0.890-1.664$ & 0.012 \\
\hline \multicolumn{4}{|l|}{ Place of residence } \\
\hline \multicolumn{4}{|l|}{ Rural $^{\circledR}$} \\
\hline Urban & $0.681 * * *$ & $0.534-0.869$ & 0.002 \\
\hline \multicolumn{4}{|l|}{ Wealth index } \\
\hline \multicolumn{4}{|l|}{ Poor $^{\circledR}$} \\
\hline Middle & 1.044 & $0.755-1.445$ & 0.791 \\
\hline Rich & 1.175 & $0.854-1.617$ & 0.322 \\
\hline \multicolumn{4}{|l|}{ Any ANC } \\
\hline \multicolumn{4}{|l|}{$\mathrm{No}^{\circledR}$} \\
\hline Yes & $1.980 * * *$ & $1.478-2.653$ & 0.000 \\
\hline \multicolumn{4}{|l|}{ Full ANC } \\
\hline \multicolumn{4}{|l|}{$\mathrm{No}^{\circledR}$} \\
\hline Yes & $1.268 * * *$ & $0.923-1.742$ & 0.000 \\
\hline \multicolumn{4}{|l|}{ Place of delivery } \\
\hline \multicolumn{4}{|l|}{ Non-Institutional $^{\circledR}$} \\
\hline Institutional & $1.100 * * *$ & $0.802-1.509$ & 0.000 \\
\hline \multicolumn{4}{|l|}{ Type of delivery } \\
\hline \multicolumn{4}{|l|}{ Normal $^{\circledR}$} \\
\hline Other & $2.367 * * *$ & $1.683-3.327$ & 0.000 \\
\hline
\end{tabular}

Note: ${ }^{\circledR}$ denotes Reference Category; $* * * \mathrm{p} \leq 0.01$, ** $\mathrm{p} \leq 0.05, * \mathrm{p} \leq 0.1 ;$ Dependent variable: Sought Treatment $(\mathrm{No}=0$, Yes $=1)$; Poor $=$ Poorest + Poorer, Rich $=$ Richest + Richer, $\mathrm{SC}=$ Scheduled Caste, $\mathrm{ST}=$ Scheduled Tribe .

\section{DISCUSSION}

This study focused on the extent of utilization of maternal health care services. Here we made a bridge between several maternal health care facilities avail from the various health sector to understand the impact of individual healthcare facilities on the utilization of health care services. Further, it helps to find out the association 
on the extent of utilization of maternal health care services and role of several socio-economic factors. The findings suggest that the level of utilization of full antenatal care is quite low compared to any ANC in Haryana. The utilization of antenatal care is more among women whose age at first marriage is 18 years and above as compared to those who married below 18 years. The social factors such as religion and caste also play a significant role in terms of receiving maternal health care services. The share of receiving antenatal care services (any and full) is quite low among Muslim women rather than any other religion. Further, more than half of the Muslim women prefer home as a place of delivery. They are less likely to seek treatment for post-delivery complication as well. It could be because of the social and cultural taboos present in some religion in India. ${ }^{21}$

The analysis further revealed that literate women are more likely to receive antenatal care as compared to their illiterate counterparts. The study also demonstrates that both any ANC and full ANC have an important role in raising the level of institutional delivery. Previous studies also revealed that an antenatal visit is a powerful tool in raising awareness regarding the institutional delivery and post-delivery treatment-seeking behavior with a significant effect of contact with health professionals. ${ }^{7,10}$ Living status of women which is measured by wealth index, differences in the educational levels of mothers, are the crucial determinants for access to the safe delivery (institutional delivery). Early marriages of the girl child and its negative impact on their health have been seen widely. ${ }^{18,22}$ It is also found that the post-delivery complication is low among literate women. Also, poor women are less likely to seek treatment to overcome post-delivery complications. Only education acts as a safeguard for marriage at an early age as well as improvement in the standard of living of women, which are finally contributing to the safe delivery and improved maternal health outcomes.

With regard to the place of residence, it was found that an urban area was consistently associated with an increased likelihood of the utilization of maternal health services. This was significant for all the indicators of maternal health services such as antenatal care, institutional delivery, and post-natal care. Thus, it is evident from the analysis that women who did not receive any kind of prenatal services due to lack of awareness and information they are very less likely in seeking treatment for post-delivery complication. Institutional delivery is negatively associated with post-delivery complication but positively associated with treatment seeking for postdelivery complication. Although Government has launched several schemes and interventions, only less than 15 percent of women from rural areas in Haryana were receiving full ANC. Nearly, one-fourth of the women prefer home as a place of delivery. Younger aged mothers were under a severe threatening towards delivery complications, which enhance the chance of death of the mother in most of the developing countries. ${ }^{19,20}$ Therefore, the post-delivery complication is also quite high among them and due to lack of financial support and the negligence and lack of awareness make a lower proportion of the women seeking treatment.

\section{CONCLUSION}

Empowering women through education should be one of the most fundamental strategies to promote health and reduce inequalities. The findings of this study too indicate that women's education has a strong potential to improve access for poor pregnant women to safe delivery services that can reduce the disparities in maternal mortality outcomes in resource-poor economies. Maternal health care services will provide a better result with increasing mother's education.

The outcome of this study also validates that the usage of antenatal care increases the likelihood of having institutional delivery which eventually increases the treatment seeking for post-delivery complications. So, it is crucial to promote the use of antenatal care among pregnant women. The access to maternal and health services for women who belong to the poor economic background is very limited. So, study suggests there is a strong need for exhilarating the coverage of maternal health care services among poor women. This study has some limitations. Firstly, the study captures post-delivery complication faced by women only based on selfreporting and data does not cover any medical authentication. Secondly, the present study is restricted to Haryana state only. There is a huge scope for further research to find out the role of health professionals and their perspective about the interventions about maternal health care services.

\section{ACKNOWLEDGMENTS}

The authors would like to thank International Institute for Population Sciences, Mumbai for providing the District Level Household and Facility Survey (DLHS) - 4, 201213 data. Authors are also grateful to the field visitors, collected such valuable information about maternal health.

\section{Funding: No funding sources Conflict of interest: None declared Ethical approval: Not required}

\section{REFERENCES}

1. Zahr CA, Wardlaw TM, Choi Y. Maternal mortality in 2000: estimates developed by WHO, UNICEF and UNFPA. World Health Organization; 2004.

2. UNICEF. The state of the world's children 2009: maternal and newborn health. Unicef; 2008. Available at https://www.unicef.org/sowc09/docs/ SOWC09-FullReport-EN.pdf. Accessed on 15 September 2017.

3. Registrar General of India. Special bulletin on maternal mortality in India 2010-12. New Delhi: 
Office of the Registrar General of India; 2013. Available at http://www.censusindia.gov.in/ vital_statistics/SRS_Bulletins/MMR_Bulletin-201012.pdf. Accessed on 15 September 2017.

4. Jahn A, De Brouwere V. Referral in pregnancy and childbirth: concepts and strategies. In: Van Lerberghe W, De Brouwere V, eds. Safe motherhood strategies: a review of the evidence studies in health services organisation and policy. 17th ed. Antwerp: ITG press; 2001:225-42.

5. Pallikadavath S, Foss M, Stones RW. Antenatal care: provision and inequality in rural north India. Soc Sci Med. 2004;59(6):1147-58.

6. Yuster EA. Rethinking the role of the risk approach and antenatal care in maternal mortality reduction. Int J Gynecol Obstet. 1995;50:S59-61.

7. Ram F, Singh A. Is antenatal care effective in improving maternal health in rural Uttar Pradesh? Evidence from a district level household survey. J Biosocial Sci. 2006;38(4):433-48.

8. Gogoi M, Unisa S, Prusty RK. Utilization of maternal health care services and reproductive health complications in Assam, India. J Public Health. 2014;22(4):351-9.

9. Singh PK, Rai RK, Alagarajan M, Singh L. Determinants of maternity care services utilization among married adolescents in rural India. PloS one. 2012;7(2):e31666.

10. Panda M, Vashisht BM. Practices related to delivery and antenatal care among females in rural block of Haryana, India. Muller J Med Sci Res. 2014;5(1):3942.

11. Govindasamy P, Ramesh BM. Maternal education and the utilization of maternal and child health services in India. Mumbai, International Institute for Population Sciences and Calverton, Maryland, Macro International Inc;1997.

12. Thind A, Mohani A, Banerjee K, Hagigi F. Where to deliver? Analysis of choice of delivery location from a national survey in India. BMC Public Health. 2008;8(1):29.

13. Dixit P, Dwivedi LK, Ram F. Estimating the impact of antenatal care visits on institutional delivery in India: a Propensity score matching analysis. Health. 2013;5(05):862-78.
14. Chandrashekar S, Rao RP, Nair NS, Kutty PR. Socio-demographic determinants of antenatal care. Tropical Doctor. 1998;28(4):206-9.

15. Dwivedi LK, Reshmi RS. Role of antenatal care in utilizing maternal health care services in Maharashtra. In: Singh KK, Yadava RC, Pandey A, eds. Population, Poverty and Health. New Delhi, Hindustan Publishing Corporation; 2009:207-16.

16. Navaneetham K, Dharmalingam A. Utilization of maternal health care services in Southern India. Social Sci Med. 2002;55(10):1849-69.

17. International Institute for Population Sciences. District Level Household and Facility Survey-4: state fact sheet Haryana, 2013. Available at https://www.rchiips.org/pdf/dlhs4/report/HR.pdf.

18. Fatusi AO, Hindin MJ. Adolescents and youth in developing countries: Health and development issues in context. J Adolescence. 2010;33(4):499-508.

19. Omer SB, Goodman D, Steinhoff MC, Rochat R, Klugman KP, Stoll BJ, et al. Maternal influenza immunization and reduced likelihood of prematurity and small for gestational age births: a retrospective cohort study. PLoS Med. 2011;8(5):e1000441.

20. Stewart K, Sommerfelt E. Utilization of maternity care services: a comparative study using DHS data. [Unpublished] 1991. Presented at the Demographic and Health Surveys World Conference Washington DC; 1991

21. Bobhate P, Shrivastava S. A cross sectional study of knowledge and practices about reproductive health among female adolescents in an urban slum of Mumbai. J Fam Reprod Health. 2011;5(4):117-24.

22. Godha D, Hotchkiss DR, Gage AJ. Association between child marriage and reproductive health outcomes and service utilization: a multi-country study from South Asia. J Adolescent Health. 2013;52(5):552-8.

Cite this article as: Ray S, Bhandari P, Prasad JB. Utilization pattern and associated factors of maternal health care services in Haryana, India: a study based on district level household survey data. Int J Reprod Contracept Obstet Gynecol 2018;7:1154-63. 